\title{
Dinastias políticas e poder local: o caso do município de Arcos-MG
}

\author{
Sabrina de Carvalho Ribeiro \\ Orientador: Débora Messenberg Guimarães \\ Dissertação de Mestrado \\ Data da defesa: 30.08.2012
}

\begin{abstract}
A pesquisa aborda o tema das dinastias políticas, marcando a transmissão do capital político e o poder local. Tem por objetivo analisar as dinastias políticas presentes no campo político parlamentar de Arcos-MG. Buscouse entender, principalmente, como as suas práticas são moldadas de forma a conviver com a estrutura do Estado Republicano e democrático. Foram analisados os capitais políticos, as práticas, os códigos de socialização, os recursos materiais e simbólicos, as alianças e redes sociais dos agentes e das famílias com tradição política. Para tanto, realizou-se uma pesquisa etnográfica e entrevistas com os atuais vereadores e presidentes de partidos políticos do município. A pesquisa buscou compreender os fundamentos e as bases para a reprodução política de membros dessas dinastias, estudando os seus perfis e trajetórias políticas.
\end{abstract}

Restou comprovado que o parentesco, na política, é um elemento constitutivo do campo político arcoense e dotado de uma racionalidade própria. A transmissão das heranças políticas é uma das estratégias centrais para o recrutamento de agentes políticos e vem sendo ressignificada.

Os resultados mostram que existem três famílias que representam as grandes lideranças do município e que quase todos os vereadores com altas taxas de reeleição na história da Câmara Municipal, e em especial na atual legislatura, são vinculados a uma dessas três famílias. A falta de parentesco ou aliança/apadrinhamento inviabiliza quase que completamente a construção de uma carreira política duradoura em Arcos.

Restou demonstrado que a eficácia da transmissão da herança política dentro das dinastias depende da socialização política do herdeiro, que envolve, entre outras coisas, o gosto pela política, a incorporação da importância da memória e da simplicidade no trato com o eleitor, a precaução em saber avaliar os pedidos da base eleitoral, ao ponderar sobre as consequências em termos de sua negativa ou aceite. Depende, também, de seus atributos pessoais, da sua compatibilidade com relação à imagem da família e sua capacidade de reedição do capital recebido, de incorporação de novos elementos à luta política, afinal, 
ele é o novo responsável pela perpetuação e atualização da dinastia.

As famílias com mais tradição no campo político, desde a emancipação do município, não só conseguiram se manter após o novo ordenamento jurídico de 1988, como, em geral, aumentaram sua presença e votação. Isso demonstra como as dinastias políticas convivem com as estruturas democráticas, sem com elas rivalizar. Observa-se que as formas de transmissão do capital político e as próprias trajetórias políticas adaptaram-se às mais variadas exigências do campo ao longo dos anos.

Dessa forma, a presente dissertação contribui para o debate sobre dinastias políticas e para a afirmação de que este não é um assunto "resolvido", cuja existência necessita ser transposta pela modernidade política.

Palavras-chave: Dinastias políticas, Heranças Políticas, Capitais Políticos. 